\title{
Investigation of Protective Effect of Matricaria Chamomilla L. Extract on Methotrexate-Induced Hepatotoxicity in Wistar Rat
}

\author{
Maral Soltani Afarani ${ }^{1}$ \\ https://orcid.org/0000-0002-8742-7458 \\ Mohammad Mohammadi ${ }^{2}$ \\ https://orcid.org/0000-0003-2380-2615 \\ Maryam Monsef Shokri ${ }^{3}$ \\ https://orcid.org/0000-0002-6411-845X
}

\section{Sara Mohammadzadeh ${ }^{4 *}$ \\ https://orcid.org/0000-0002-5455-6499}

\begin{abstract}
${ }^{1}$ Science and Research Branch, Department of Biology, Islamic Azad University, Tehran, Iran; ${ }^{2}$ Shahid Chamran University of Ahvaz, , Faculty of Science, Department of Biology , Ahvaz, Iran; ${ }^{3}$ International Sturgeon Research Institute, Agricultural Research, Education and Extension Organization (AREEO), Rasht, Iran; ${ }^{4}$ Kermanshah University of Medical Sciences, Medical Biology Research Center, Kermanshah, Iran.
\end{abstract}

Received: 2018.11.07; Accepted: 2020.03.17.

${ }^{*}$ Correspondence: s.mohamadzade9@gmail.com; Tel.: +98-83-34276473

\section{HIGHLIGHTS}

- The chamomile extract improved MTX-induced liver histopathological and biochemical changes.

- The improvement was significant in the rats that were treated with higher dose of extract $\left(\mathrm{CE}_{300}\right)$.

- The extract enhanced anti-oxidant defense system and decreased MTX-induced oxidative damage.

Abstract: Methotrexate (MTX) was shown to cause oxidative stress and liver damage. The objective was to investigate the possible protective effects of Matricaria Chamomilla L. (chamomile) extract with anti-oxidant and anti-inflammatory properties on the methotrexate-induced liver toxicity. Twenty four Wistar rats were divided into four groups. MTX group was injected intraperitoneally on days 7 and 14 with $20 \mathrm{mg} / \mathrm{kg}$ methotrexate. Groups $\mathrm{CE}_{200}$ (chamomile extract $200 \mathrm{mg} / \mathrm{kg} /$ day) and $\mathrm{CE}_{300}$ (chamomile extract 300 $\mathrm{mg} / \mathrm{kg} /$ day) received the same dose of methotrexate added with chamomile extract orally for 15 days at 200 $\mathrm{mg} / \mathrm{kg}$ and $300 \mathrm{mg} / \mathrm{kg}$ respectively and the last group was healthy control group. Results of biochemical analyses indicated serum liver biomarkers (aminotransferases), alkaline phosphatase (ALP), albumin, and liver content of anti-oxidant enzymes (catalase (CAT), superoxide dismutase (SOD), glutathione peroxidase $(\mathrm{GSH}-\mathrm{Px}))$, reduced glutathione $(\mathrm{GSH})$ and total anti-oxidant capacity $(\mathrm{TAC})$ significantly increased $(\mathrm{P}<0.05$ 0.001 ) to normal in the CE treated groups compared to those of the MTX group. Serum bilirubin and hepatic malondialdehyde (MDA) levels significantly increased $(P<0.001)$ in MTX group compared to those of the control group and decreased in $\mathrm{CE}_{200}$ and $\mathrm{CE}_{300}$ groups compared to those of the MTX group. Histopathological study showed inflammatory damage, necrotic cells and lipid infiltration in MTX group. In the groups treated with the chamomile extract, a significant improvement was observed in liver tissue in response 
to increased dose of the extract. In conclusion, chamomile extract administration could have a protective role in methotrexate-induced liver toxicity in rats through improving anti-oxidant defense system.

Keywords: methotrexate; chamomile extract; hepatotoxicity; oxidative stress; anti-oxidant.

\section{INTRODUCTION}

The liver is an important and central organ involved in many metabolic functions, decomposition of toxic and excessive substances, and the excretion of drugs from the body. Liver injury is one of the most significant mechanisms of drug-induced hepatotoxicity due to irregular liver function accompanied by oxidative damages [1]. One of the medicines which could result in liver damage is methotrexate (MTX). This drug is used at low doses for the treatment of various inflammatory and autoimmune diseases, including rheumatoid arthritis, juvenile idiopathic arthritis and psoriasis, as well as at high doses for treating various types of cancers [2,3]. However, the efficiency of this agent at high doses or long-term therapy is related to its hepatotoxicity and some of the known side effects include hematologic complications, lung and intestinal toxicity $[3,4]$. The mechanism of liver damage caused by methotrexate has not been clearly specified; nevertheless, it has been reported that methotrexate causes oxidative stress and inflammation in the liver tissue. The oxidative tissue damage is to be considered as the main factor contributing to the emergence and the progression of pathogenicity and hepatotoxicity due to the use of methotrexate. It increases reactive oxygen species (ROS) along with the reduction of the anti-oxidant defense system and consequently leads to the accumulation of leukocytes and increased release of pro-inflammatory cytokines in the liver tissue [2,5-7].

Methotrexate is a folic acid antagonist. The therapeutic effects and complications caused by methotrexate use are due to its ability particularly to inhibit dihydrofolate reductase and thymidylate synthase enzymes that are essential for DNA and RNA synthesis [8]. The drug decreases the intracellular NADPH by inhibiting the pentose phosphate pathway [9]. Under normal circumstances, NADPH is used to maintain the reduced glutathione store which as an important cytosolic anti-oxidant plays a protective role against ROS. Therefore, decreasing the level of NADPH due to the administration of methotrexate can decrease the glutathione level and thus increase the liver cells sensitivity to released radicals, which leads to liver damage [10]. Moreover, the methotrexate-polyglutamate form is considered as another cause of hepatotoxicity due to prolonged accumulation of MTX in liver cells. Although 7-hydroxymethotrexate (7-OH-MTX) is a major metabolite of methotrexate, methotrexate is metabolized and stored in polyglutamine form in the liver cells [5].

Since most of the synthetic drugs have side effects, finding inexpensive herbal medicines with protective effects as complementary therapy is desired. Furthermore, various studies have been conducted on the protective effect of extracts and plant compounds against damages due to the drugs consumption $[1,3,11]$.

Chamomile (Figure 1) is one of the most important plants in traditional medicine to treat various human ailments such as inflammation, rheumatism, and gastrointestinal disorder, as well as to boost the immune system. The German or common chamomile (Matricaria chamomilla L.) belongs to the Asteraceae family, the capitols of which are exclusively used [12,13]. Over 120 metabolites including amino acids, polysaccharides, fatty acids, terpenoids, flavonoids, and phenolic derivatives have been identified in chamomile flowers. The best known bioactive chemical elements in chamomile flowers include apigenin, quercetin, luteolin, the terpenoids $\alpha$-bisabolol and its oxides, and chamazulene [12,14]. The chamomile plant is rich in flavonoids, which are effective anti-oxidants in scavenging free radicals and preventing the oxidative damage on cellular components [15]. Apigenin is one of the flavonoids in chamomile to which the antiinflammatory, anti-oxidant activity, anti-mutagenesis and antitumor effects can be attributed [16]. Apigenin with anti-inflammatory effect is a versatile compound for the treatment of neurodegenerative diseases which inhibit the production of pro-inflammatory cytokines generated by leukocytes $[16,17]$.

Various studies have confirmed the protective effects of anti-oxidant plants on liver damage and chamomile plant is one of the richest sources of dietary anti-oxidants; however, no study in the field of protective effects of chamomile plant on liver damage caused by methotrexate has been conducted so far. In the present study, the protective effects of chamomile extract are investigated on methotrexate-induced hepatotoxicity in rats. 


\section{MATERIAL AND METHODS}

\section{Chemicals and equipments}

Methotrexate was purchased from Ebewe (Austria). Bovine serum albumin (BSA), 5,5'-dithiobis-2nitrobenzoate (DTNB), nitroblue tetrazolium (NBT) and hydroxylamine hydrochloride were purchased from Sigma-Aldrich Co. (USA). Unless otherwise specified, all chemicals and regents were from Merck Co. (Germany).

Rotary evaporator (IKA, RV 10, Germany), mechanical grinder (Labtron Co., Iran), Cobas Mira autoanalyzer (Roche; Basel, Switzerland), Miccra D-8 homogenizer (ART, Germany), microplate spectrophotometer PowerWave XS2 (BioTek Instruments, Inc., USA), refrigerated centrifuge (Sartorius, Germany), and microtome (Leica, Germany) were used for biological experiments.

\section{Animals}

The methods and research steps were approved by the Ethics Committee of Islamic Azad University, Science and Research Branch, Tehran, Iran (Code: IR.IAU.SRB.REC.1395.50), and all the ethical points of working with animals were observed. Twenty-four male Wistar rats (8 weeks of age; mean body weight 200 $\pm 50 \mathrm{~g}$ ) were used. The rats were purchased from Ahvaz Jundishapur University of Medical Sciences. The rats were transferred to the standard condition and kept at $23 \pm 2{ }^{\circ} \mathrm{C}$ with 12 hours of light and 12 hours of darkness to adapt to the environment one week before the start of the study. The rats were fed with standard food and water made available to them unlimitedly and no vaccines or other medicines were used.

\section{Plant material and extract preparation}

Chamomile, as it shown in Figure 1, was collected from the village of Kouhbad, Khouzestan (31.4360 $\left.\mathrm{N}, 49.0413^{\circ} \mathrm{E}\right)$, Iran in April 2016. The plant material was identified as Matricaria chamomilla L. according to the two reference samples with the numbers 404 and 405 at the herbarium unit of Shahid Chamran University of Ahvaz.

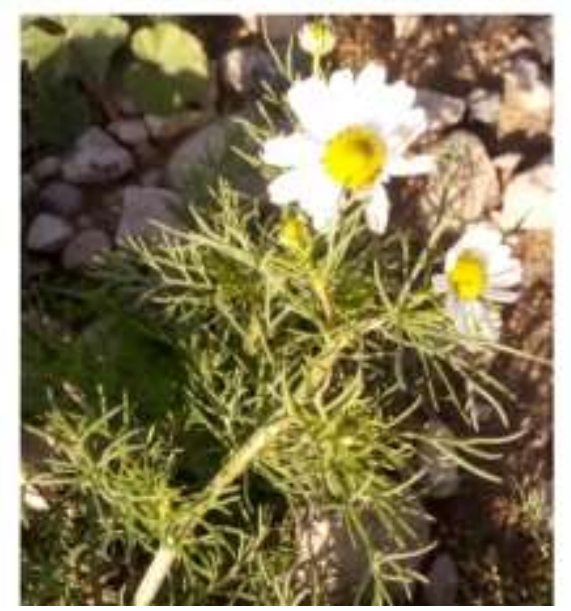

Figure 1. Matricaria chamomilla L. growing in Kouhbad, Khouzestan, Iran.

Chamomile flowers were dried in shade at room temperature until they were out of moisture (almost 10 days) and fine powder was prepared using a mechanical grinder. A total of $280 \mathrm{~g}$ of the obtained powder was dissolved in $70 \%$ ethyl alcohol to give a total volume of one liter. After 72 hours at $25^{\circ} \mathrm{C}$ with agitation every 12 hours, the solution was passed through Whatman filter paper 42 . The filtered solution was then concentrated with a rotary device at $40{ }^{\circ} \mathrm{C}$ and a speed of $70 \mathrm{rpm}$ to one third of the initial volume. The obtained extract was dried in glass containers at $40^{\circ} \mathrm{C}$. Then by adding normal saline $(0.9 \% \mathrm{NaCl})$, an extract with the desired concentration was prepared. The obtained solution was kept at $4^{\circ} \mathrm{C}$ and away from light until the gavage use on the same day.

\section{Experiment design}

The rats were randomly divided into four groups of six. Those in control group were injected intraperitoneally on days 7 and 14 with $0.5 \mathrm{~mL}$ of normal saline and also orally received $5 \mathrm{~mL}$ of distilled water 
daily by gavage for 16 days. The MTX group (non-treated test group) was injected intraperitoneally on days 7 and 14 with methotrexate at $20 \mathrm{mg} / \mathrm{kg}$ body weight and received distilled water daily by oral gavage for 16 days. In $\mathrm{CE}_{200}$ (chamomile extract $200 \mathrm{mg} / \mathrm{kg} /$ day) group, methotrexate was administered intraperitoneally on days 7 and 14 at $20 \mathrm{mg} / \mathrm{kg}$ body weight and they also received hydroalcoholic chamomile extract daily at $200 \mathrm{mg} / \mathrm{kg} /$ day by oral gavage for 16 days, while the last group or $\mathrm{CE}_{300}$ (chamomile extract $300 \mathrm{mg} / \mathrm{kg} / \mathrm{day}$ ) group received the same dose of methotrexate plus hydroalcoholic chamomile extract at $300 \mathrm{mg} / \mathrm{kg} / \mathrm{day}$ orally for 16 days.

\section{Sample preparation for biochemical analysis}

After the end of the treatment, the rats were fasted for 12 hours and were then anesthetized with diethyl ether. Blood samples were collected from their hearts and the serum was separated by centrifugation at 3000 rpm for 10 minutes at $4{ }^{\circ} \mathrm{C}$ and then stored at $-70^{\circ} \mathrm{C}$ until analysis was done. The sera were used to measure aspartate aminotransferase (AST), alanine aminotransferase (ALT), alkaline phosphatase (ALP), albumin, and bilirubin. These assays were measured using the Pars Azmoon Company kits (Iran) by the autoanalyzer.

A part of the liver tissue was also taken for histopathologic studies and measuring the oxidative stress parameters including malondialdehyde (MDA), reduced glutathione (GSH), catalase (CAT), superoxide dismutase (SOD), glutathione peroxidase (GSH-Px), and total anti-oxidant capacity (TAC). For analysis of the hepatic oxidative stress parameters, one gram of liver tissue was homogenized with 5 volumes of icecold PBS buffer for 2 minutes at $7000 \mathrm{rpm}$. The homogenized material was then centrifuged at $13000 \mathrm{rpm}$ for 5 minutes and the supernatant was isolated.

\section{Total protein assay}

The protein content of the liver tissue was measured by the Bradford method [18]. $40 \mu \mathrm{L}$ of the sample was poured into a 96 microplate and $180 \mu \mathrm{L}$ of Bradford reagent $(10 \mathrm{mg}$ Coomassie Blue R-250 was dissolved in $5 \mathrm{~mL}$ of $95 \%$ ethanol and $10 \mathrm{~mL}$ of $85 \%$ phosphoric acid, and diluted to $100 \mathrm{~mL}$ of distilled water and was then filtered through Whatman filter paper) were added. After 10 minutes, the absorbance was measured spectrophotometrically at $595 \mathrm{~nm}$. For the preparation of standard curve, different concentrations of bovine serum albumin (BSA) in the range of $0.15-0.5 \mathrm{mg} / \mathrm{mL}$ were used.

\section{Malondialdehyde assay}

MDA as a reliable marker of lipid peroxidation, was determined in tissue homogenate by the thiobarbituric acid (TBA) reaction [19]. Briefly, for each sample, the reaction mixture consisted of $0.25 \mathrm{~mL}$ of liver homogenate and $0.5 \mathrm{~mL}$ of working solution (a mixture of $15 \%$ trichloroacetic acid and $0.375 \%$ TBA in 0.25 $\mathrm{N}$ hydrochloric acid). The mixture was heated in boiling water bath for 15 minutes and after cooling, the tubes were centrifuged for 10 minutes at $3000 \mathrm{rpm}$. The absorbance of the supernatant was then measured at 532 $\mathrm{nm}$ and the values of MDA were determined by using the standard curve and were expressed as $\mu \mathrm{mol} / \mathrm{L}$.

\section{Total anti-oxidant capacity}

TAC was measured according to the method of Benzie and Strain [20], based on the ferric reducing antioxidant power (FRAP) assay. The fresh working solution of FRAP was prepared by mixing: $25 \mathrm{~mL}$ acetate buffer (300 mM, pH 3.6), $2.5 \mathrm{~mL}$ TPTZ (2, 4, 6-tripyridyl-s-triazine) solution (10 mM TPTZ in $40 \mathrm{mM} / \mathrm{HCl}$ ), and $2.5 \mathrm{~mL} \mathrm{FeCl} 36 \mathrm{H}_{2} \mathrm{O}$ solution $(20 \mathrm{mM}) .5 \mu \mathrm{L}$ of serum was mixed with $240 \mu \mathrm{L}$ of the working solution and were incubated for 10 minutes at $37^{\circ} \mathrm{C}$. The optical density of the samples was measured at $593 \mathrm{~nm}$. A standard curve was prepared using different concentrations of iron (II) sulfate solution that were expressed as $\mu \mathrm{mol}$ $\mathrm{Fe}(\mathrm{II}) / \mathrm{mL}$.

\section{Glutathione measurement}

The amount of GSH in tissue homogeneity was determined by measuring the reaction of the thiol groups with Ellman's method [21] based on the reaction of thiols with the chromogenic 5,5'-dithiobis-2-nitrobenzoate (DTNB) to form the yellow dianion of 5 -thio-2-nitrobenzoic acid (TNB). $5 \mu \mathrm{L}$ of Ellman's reagent $(4 \mathrm{mg}$ of DTNB dissolved in $1 \mathrm{~mL}$ of $0.1 \mathrm{M}$ phosphate buffer $\mathrm{pH} 8$ and $1 \mathrm{mM}$ EDTA), and $250 \mu \mathrm{L}$ of $0.1 \mathrm{M}$ phosphate buffer $\mathrm{pH} 8$ and $1 \mathrm{mM}$ EDTA were added to the microplate well followed by the addition of $25 \mu \mathrm{L}$ of the sample. After 15 minutes of incubation, the absorbance of the reaction mixture was read at $412 \mathrm{~nm}$. The 
amount of thiol groups was calculated from the prepared corresponding standard curve using the same volume of solutions containing 25 to $150 \mu \mathrm{mol} / \mathrm{L}$ of cysteine hydrochloride.

\section{Measurement of glutathione peroxidase activity}

GSH-Px activity in liver tissue homogenates was measured by the Randox ${ }^{\circledR}$ kit (UK), based on the method of Paglia and Valentine [22].The assay was performed on a haemolysate according to the instruction kit. A standard curve was prepared by using the standard provided in the kit and the value for each sample was read from this curve.

The activity of GSH peroxidase was expressed as $\mathrm{U} / \mathrm{mg}$ protein and calculated from the following formula: GPX U/mg protein = GPX U/mL/protein concentration $/ \mathrm{mL}$. GPX U/L of sample $=8412 \times \Delta A 340$ $\mathrm{nm} / \mathrm{min} ; \Delta \mathrm{A}=$ difference of blank value from sample value.

\section{Superoxide dismutase}

The activity of SOD in liver homogenates was estimated by using the method of Kono [23]. The method is based on the principle of the inhibitory effect of SOD on reduction of nitroblue tetrazolium (NBT) to the formation of red dye by superoxide anions, which are generated by the photo-oxidation of hydroxylamine hydrochloride. The reaction mixture contained $130 \mu \mathrm{L}$ of solution A ( $50 \mathrm{mM}$ sodium carbonate, $0.1 \mathrm{mM}$ EDTA, $\mathrm{pH} 10.0)$ and $50 \mu \mathrm{L}$ of solution $\mathrm{B}(96 \mu \mathrm{M} \mathrm{NBT}$ and $0.1 \mathrm{~mL}$ of $0.6 \%$ Triton X-100). The reaction was initiated by the addition of $50 \mu \mathrm{L}$ of $20 \mathrm{mM}$ hydroxylamine hydrochloride $(\mathrm{pH} 6.0)$ and $20 \mu \mathrm{L}$ sample. The rate of NBT reduction was measured at $560 \mathrm{~nm}$ using a spectrophotometer during 5 minutes. \%Inhibition of NBT reduction was calculated from the following formula:

$$
\text { Inhibition }(\%)=\left(A_{560 \text { control }}-A_{560 \text { sample }} / A_{560 \text { control }}\right) \times 100
$$

\section{Catalase activity}

Measuring the amount of CAT activity in homogenous samples was done by Koroliuk and coauthors based on the amount of peroxide reduction per unit time due to the activity of present CAT enzyme in the sample [24]. In brief, $5 \mu \mathrm{L}$ of the liver homogenate was added to $50 \mu \mathrm{L}$ of $50 \mathrm{mM}$ Tris $-\mathrm{HCl}(\mathrm{pH} 7.4)$ in microplate well. After addition of $100 \mu \mathrm{L}$ of $\mathrm{H}_{2} \mathrm{O}_{2}$, the reaction mixture was incubated for 10 minutes at room temperature. The reaction was stopped by adding $100 \mu \mathrm{L}$ of $4 \%$ ammonium molybdate and the absorbance was read versus blank at $410 \mathrm{~nm}$. CAT activity was calculated by the formula:

$$
\mathrm{CA}=\left(A_{410 \text { sample }}-A_{410 \text { control }}\right) / A_{410 \text { control }}
$$

\section{Histopathological examination}

Tissue samples of the rats' livers were obtained and kept in $10 \%$ formalin. After the stages of tissue preparation and making paraffin blocks, 5 micron sections of the tissues were prepared and stained with hematoxylin and eosin (H\&E). Afterward, they were studied by light microscopy and tissue damage was evaluated.

\section{Statistical analysis}

All experiments were performed at least three times with $n=6$ per group. The data were analyzed with Prism software version 6 (GraphPad Software, San Diego, CA) and the results were expressed as mean \pm standard deviation (S.D.). Statistically, significant differences between groups were measured using one-way ANOVA followed by Tukey's post-hoc test, and a $P$ value of $<0.05$ was considered statistically significant.

\section{RESULTS}

The effect of methotrexate on serum levels of ALT, AST, ALP, bilirubin and albumin in test groups is shown in Table 1. The mean activity of AST, ALT and ALP as well as albumin level in the methotrexate receiver group with no further treatment (MTX group) decreased significantly compared to the control group $(P<0.001)$. Treatment with hydroalcoholic extract of chamomile caused a significant increase to normal in AST, ALT, ALP and albumin in $\mathrm{CE}_{200}$ group (methotrexate + chamomile extract at $200 \mathrm{mg} / \mathrm{kg} / \mathrm{day}$ ) and $\mathrm{CE}_{300}$ group (methotrexate + chamomile extract at $300 \mathrm{mg} / \mathrm{kg} / \mathrm{day}$ ) in response to the increased dose of the extract. 
The mean of serum bilirubin in the MTX group increased significantly compared to control group (P $<0.001)$. Treatment with chamomile extract caused a significant reduction of bilirubin in $\mathrm{CE}_{200}$ and $\mathrm{CE}_{300}$ groups compared to MTX group $(P<0.001)$.

Table 1. Serum levels of AST, ALT, ALP, albumin and bilirubin in the studied groups.

\begin{tabular}{|c|c|c|c|c|c|}
\hline Groups $^{1}$ & bilirubin (mg/dL) & $\begin{array}{r}\text { Albumin } \\
\text { (mg/dL) }\end{array}$ & $A L P(U / L)$ & $\overline{A L T(U / L)}$ & $\overline{\mathrm{AST}(\mathrm{U} / \mathrm{L})}$ \\
\hline Control & $0.15 \pm 0.02$ & $4.62 \pm 0.37$ & $478.8 \pm 34.97$ & $58.8 \pm 7.51$ & $230.8 \pm 27.5$ \\
\hline MTX & $0.28 \pm 0.035$ & ${ }^{*} 3.11 \pm 0.21$ & *234.16 \pm 50.65 & ${ }^{*} 30.33 \pm 6.43$ & ${ }^{* *} 150.8 \pm 20.28$ \\
\hline $\mathrm{CE}_{200}$ & ${ }^{\mathrm{c}} 0.19 \pm 0.02$ & a $3.71 \pm 0.29$ & $290.16 \pm 41.5^{a}$ & b $43.33 \pm 3.18$ & $153.3 \pm 17.96$ \\
\hline $\mathrm{CE}_{300}$ & ${ }^{\mathrm{c}} 0.17 \pm 0.02$ & ${ }^{\circ} 4.15 \pm 0.41$ & b $317.66 \pm 38.37$ & c $50.5 \pm 2.95$ & $178 \pm 21.14$ \\
\hline
\end{tabular}

1 In each group there are 6 male rats. The first group is the healthy control group; the MTX group is the non-treated test rats receiving methotrexate, Groups $\mathrm{CE}_{200}$ and $\mathrm{CE}_{300}$ received the same dose of methotrexate added with hydroalcoholic chamomile extract orally for 15 days at $200 \mathrm{mg} / \mathrm{kg} /$ day and $300 \mathrm{mg} / \mathrm{kg} /$ day respectively. In the comparison of MTX group to healthy control group, * $(P<0.05),{ }^{* *}(P<0.01)$, ${ }^{* * *}(P<0.001)$ were considered statistically significant. In the comparison of $C E_{200}$ and $C E_{300}$ groups with $M T X$ group, ${ }^{a}(P<0.05)$, ${ }^{b}(P<0.01),{ }^{c}(P<0.001)$ were considered statistically significant. The numbers are displayed as Mean \pm SD.

In Table 2, the effect of methotrexate on the levels of liver malondialdehyde, glutathione, total anti-oxidant capacity, activity of catalase, glutathione peroxidase, and superoxide dismutase enzymes is indicated in test groups. In the present study, the administration of methotrexate significantly decreased the activity of the SOD, GSH-Px, and CAT as the enzymatic anti-oxidant defenses compared to the control group $(\mathrm{P}<0.01$ 0.001).T

Table 2. Anti-oxidant activity of rat liver in the studied groups

\begin{tabular}{|c|c|c|c|c|c|c|}
\hline Groups & $\begin{array}{c}\text { CAT (U/mg } \\
\text { protein) }\end{array}$ & $\begin{array}{c}\text { GSH-Px } \\
\text { (U/mg } \\
\text { protein) }\end{array}$ & $\begin{array}{c}\text { SOD (U/mg } \\
\text { protein) }\end{array}$ & $\begin{array}{c}\text { GSH } \\
\mu \mathrm{mol} / \mathrm{mg} \text { ) } \\
\text { (protein }\end{array}$ & $\begin{array}{c}\text { MDA } \\
\text { ( } \mu \mathrm{mol} / \mathrm{mg} \\
\text { protein })\end{array}$ & $\begin{array}{c}\text { TAC } \\
\mu \text { mol } / \mathrm{mg}) \\
(\text { protein }\end{array}$ \\
\hline Control & $2.97 \pm 0.32$ & $2.61 \pm 0.07$ & $292 \pm 8.9$ & $0.36 \pm 0.03$ & $10.64 \pm 1.06$ & $0.37 \pm 0.03$ \\
\hline MTX & $2.2 \pm 0.4$ & $* \star * * 1.93 \pm 0.09$ & $217 \pm 19.7$ & $0.21 \pm 0.02$ & ${ }^{* \star} 14.31 \pm 1.5$ & ${ }^{* *} 0.30 \pm 0.01$ \\
\hline $\mathrm{CE}_{200}$ & $2.36 \pm 0.32$ & $2.16 \pm 0.3$ & c $260 \pm 7.07$ & $0.34 \pm 0.03^{c}$ & $12.67 \pm 1.5$ & $0.33 \pm 0.02$ \\
\hline $\mathrm{CE}_{300}$ & $2.77 \pm 0.28^{a}$ & $2.35 \pm 0.26^{a}$ & c $262 \pm 15.2$ & $0.35 \pm 0.02^{c}$ & $11.18 \pm 1.05^{b}$ & $0.35 \pm 0.02^{a}$ \\
\hline
\end{tabular}

In the comparison of MTX group to healthy control group, ${ }^{*}(\mathrm{P}<0.05),{ }^{* *}(\mathrm{P}<0.01),{ }^{* * *}(\mathrm{P}<0.001)$ were considered statistically significant. In the comparison of $C_{200}$ group and $C E_{300}$ group with MTX group, ${ }^{a}(P<0.05),{ }^{b}(P<0.01),{ }^{c}(P$ $<0.001$ ) were considered statistically significant. The numbers are displayed as Mean \pm SD.

As shown in Table 2, the GSH-Px activity in the MTX group decreased significantly $(P<0.001)$. However, in $\mathrm{CE}_{200}$ and $\mathrm{CE}_{300}$ groups it increased compared to MTX group. This increase was statistically significant in $\mathrm{CE}_{300}$ group $(\mathrm{P}<0.05)$. The activity of SOD in the MTX group significantly decreased compared to the control group $(P<0.001)$. But, it significantly increased in the $C E_{200}$ and $C E_{300}$ groups compared to the MTX group ( $P$ $<0.001)$. The activity of CAT in the MTX group highly decreased compared to the control group $(\mathrm{P}<0.01)$. It increased in the $\mathrm{CE}_{200}$ group, however this increase was not significant; while in the $\mathrm{CE}_{300}$ group it significantly increased compared to the MTX group $(P<0.05)$.

The total anti-oxidant capacity (TAC) in the MTX group decreased significantly compared to the control group $(P<0.01)$. The total anti-oxidant level increased significantly in the $\mathrm{CE}_{300}$ group treated with chamomile extract at a dose of $300 \mathrm{mg} / \mathrm{kg} /$ day for 15 days $(P<0.05)$.

The level of MDA increased significantly in the MTX group compared to the control group $(P<0.001)$. The administration of chamomile hydroalcoholic extract caused a significant decrease in $\mathrm{CE}_{200}$ group compared to the MTX group in MDA level in the liver tissue. However, this reduction was not significant and decreased significantly in $\mathrm{CE}_{300}$ group $(\mathrm{P}<0.01)$. 
The results indicate that the administration of methotrexate caused a significant decrease in GSH content in the MTX group compared to the control group $(P<0.001)$. While the results in the groups $C_{200}$ and $C_{300}$ treated by chamomile hydroalcoholic extract indicated that the GSH content of liver tissue increased significantly compared to the MTX group $(P<0.001)$.

As shown in Figures $2 \mathrm{~A}$ and $\mathrm{B}$, the histopathological results of liver sections of rats in control group indicated normal hepatocytes with healthy cytoplasm and recognizable nucleus and sinusoids radially from the central vein to hepatocytes. In the MTX group, as shown in Figures $2 \mathrm{C}$ and D, degeneration of liver cells and irregularities in the structure of liver lobules, dilatation and hyperemia of the central and portal veins were observed. As well as blood vessel sinusoids and their obstruction increased the number of activated Kupffer cells and infiltration of inflammatory cells in periportal area and the central vein.

As shown in Figures $2 \mathrm{E}$ and $2 \mathrm{~F}$, histopathologic results indicate that treatment with chamomile extract leads to a better effect in the healing of hepatic cells. In the $\mathrm{CE}_{200}$ group receiving $200 \mathrm{mg} / \mathrm{kg} /$ day for 15 days of chamomile extract, the level of hyperemia and inflammation were observed comparing to the other receiver group $\mathrm{CE}_{300}$ and the rate of healing was lower. As shown in Figures $2 \mathrm{G}$ and $2 \mathrm{H}$, there were no pathologic lesions observed in the $\mathrm{CE}_{300}$ group receiving $300 \mathrm{mg} / \mathrm{kg} /$ day of the extract and all of them had a closely normal structure. 


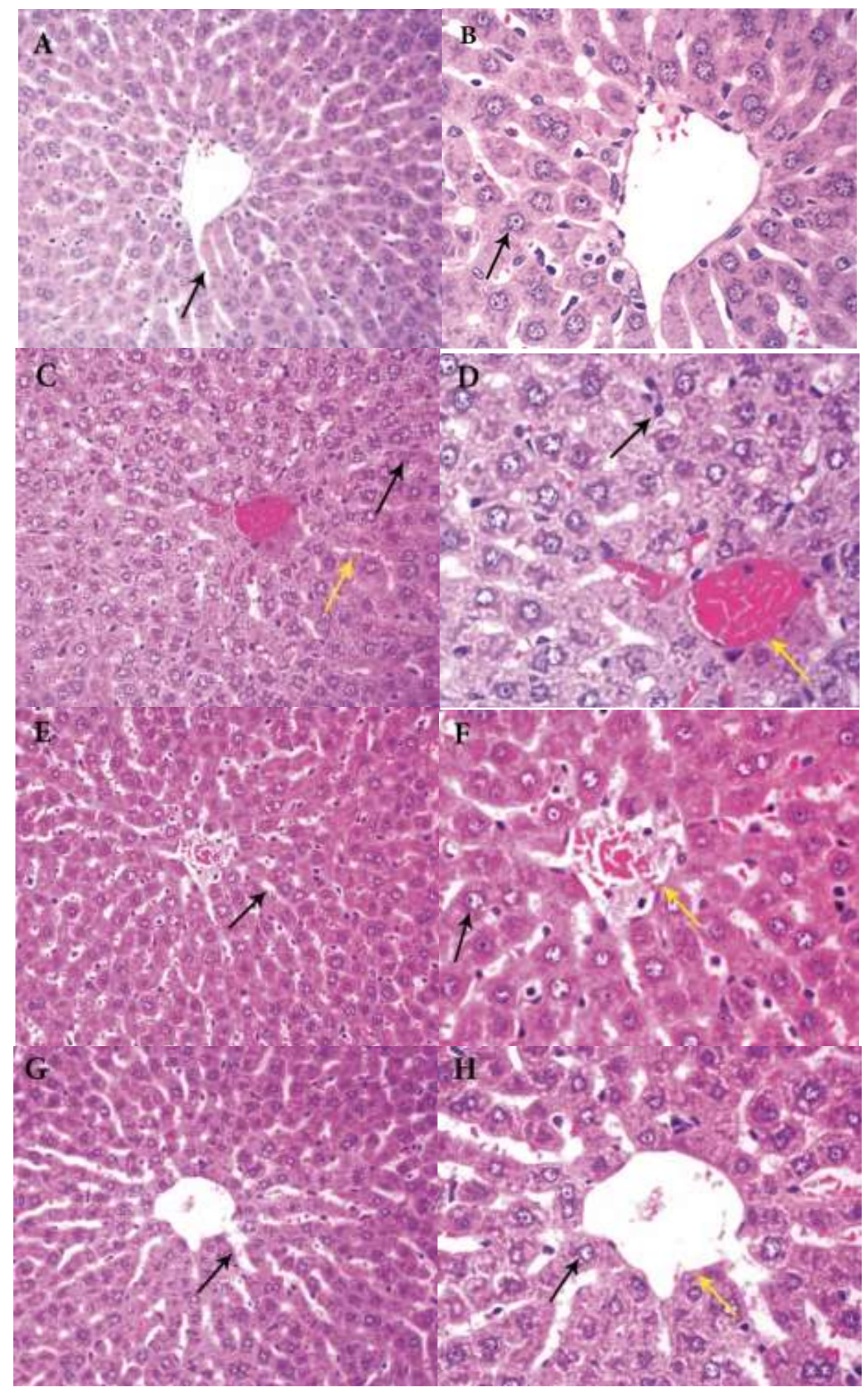

Figure 2. Liver sections of rats in the studied groups: A) Control group ( $H \& E$, objective lens $\times 20)$; the sinusoids are radially observed from the central vein towards the hepatocytes $(\uparrow)$. B) Control group $(\mathrm{H} \& \mathrm{E}$, objective lens $\times 40)$; healthy liver cells are observed normal with pink cytoplasm and nucleus of the same size with recognizable nucleolus $(\uparrow)$. C) Methotrexate group (H \& E $\times 20)$; swelling of hepatocytes and reduction of intercellular space ( $\uparrow)$. D) MTX group (H \& E $\times 40)$; the number of kupffer cells has increased ( $\uparrow)$; hyperemia of the central vein ( $\uparrow)$. E) $C E_{200}$ group treated with 200 $\mathrm{mg} / \mathrm{kg}$ chamomile extract $(\mathrm{H} \& \mathrm{E} \times 20)$; the sinusoids are radially observed from the central vein towards the hepatocytes; indicating that the cellular swelling has decreased to some extent $(\uparrow)$. F) The $\mathrm{CE}_{200}$ group $(\mathrm{H} \& \mathrm{E} \times 40)$; the liver cells are observed with pink cytoplasm and nucleus of the same size with recognizable nucleolus, indicating that the cellular swelling decreased to some extent $(\uparrow)$; and the central vein is still hyperemic ( $\uparrow)$. G) CEзso group that treated with 300 $\mathrm{mg} / \mathrm{kg}$ chamomile extract $(H \& E \times 20)$; the sinusoids are radially observed from the central vein towards the hepatocytes $(\uparrow)$. H) The $\mathrm{CE}_{300}$ group $(\mathrm{H} \& \mathrm{E} \times 40)$; the liver cells are observed with pink cytoplasm and nucleus of the same nuclei size with recognizable nucleolus $(\uparrow)$; central vein hyperemia is not observed $(\uparrow)$. 


\section{DISCUSSION}

In the present study, contrary to expectations and various earlier studies [5,25], the reduction of serum biochemical parameters (ALT, AST, ALP) was observed in MTX group in spite of multiple biological repetitions (Table 1). That's while, the histological manifestations (Figures $2 \mathrm{C}, \mathrm{D}$ ) confirmed the diagnosis of liver damage due to methotrexate use. In consistent with Shibayama and coauthors studies [26,27], since these enzymes are intracellular, they enter the serum when cell damage occurs [28]. Therefore, any reduction or increase in serum levels is considered abnormal compared to the control group. The results of previous studies also indicate that methotrexate reduces albumin level [6], which are in consistent with the results shown in Table 1. The observations are probably due to an indirect effect of methotrexate on protein synthesis by declining the amount of tetrahydrofolate [8]. Furthermore, nephrotoxicity induced by methotrexate could lead to increasing renal loss of albumin [6]. On the other hand, treatment with hydroalcoholic extract of chamomile caused a significant increase to normal in AST, ALT, ALP and albumin in $\mathrm{CE}_{200}$ group and $\mathrm{CE}_{300}$ group in response to the increased dose of the extract. This improvement is probably due to the reduction of oxidative stress and the inhibition effect of methotrexate on protein synthesis by the anti-oxidant properties of phenolic compounds present in the plant [3,14,29,30]

The results of previous studies also indicate that methotrexate causes total bilirubin to increase as another indicator of hepatotoxicity $[5,31,32]$. Treatment with chamomile extract caused a significant reduction of bilirubin. This decrease is probably due to the protection of the liver against oxidative damage caused by methotrexate $[14,29,30]$.

GSH-Px led to the destruction of free $\mathrm{H}_{2} \mathrm{O}_{2}$ in the presence $\mathrm{GSH}$ into $\mathrm{H}_{2} \mathrm{O}$ and disulfide glutathione (GSSG); it also protects the phospholipid membrane by inhibiting the peroxidation process. In the MTX group, the activity of GSH-Px enzyme is probably inhibited by decreasing GSH levels as GSH-Px substrates. Due to the function of methotrexate, changing the status of GSH levels is the result of inhibiting NADH-dependent dehydrogenase and decreasing NADPH levels $[5,28,33]$. In rats treated with chamomile hydroalcoholic extract, the GSH-Px enzyme increased in liver tissue compared to the group receiving methotrexate. This increase is probably due to the presence of phenolic compounds as anti-oxidants in the extract which trap free radicals and protect cells against oxidative stress [33-35].

Other main enzymes in the anti-oxidant defense system are SOD enzyme which converts superoxide anion into hydrogen peroxide $\left(\mathrm{H}_{2} \mathrm{O}_{2}\right)$ and CAT enzyme which decomposes $\mathrm{H}_{2} \mathrm{O}_{2}$ into water and molecular oxygen. As shown in Table 2, The decrease in the activity of these enzymes in the liver tissue of MTX group may be due to the mechanism of methotrexate in decreasing NADH levels and the change of cellular redox status, which subsequently increase the ROS types in the cell [5]. The increase in the activity of the enzymes in the treated rats with chamomile extract is due to the anti-oxidant properties of the plant in inhibiting the superoxide radicals and $\mathrm{H}_{2} \mathrm{O}_{2}$ and preventing subsequent oxidative stress by enhancing the anti-oxidant defense system. The results are consistent with earlier studies on the protective effect of chamomile $[30,34,35]$. Previous studies indicate that methotrexate causes TAC levels to reduce $[5,9,28,33]$. The reduction can be a consequence of the process of inhibiting anti-oxidant enzymes and non-enzymatic agents of the anti-oxidant defense system and using these agents in cells by free radicals. The administration of chamomile hydroalcoholic extract increased the TAC level significantly by suppressing ROS and enhancing the anti-oxidant defense ability; these results are consistent with the results of previous studies [30].

The level of MDA increased significantly in the MTX group compared to the control group $(P<0.001)$. These findings are consistent with previous studies on methotrexate-induced liver toxicity with elevated MDA levels [36,37]. Regarding the mechanism of methotrexate, which leads to increased oxidative stress, MDA is a metabolite of lipid peroxidation induced by free radicals. These radicals can oxidize protein groups and other cellular macromolecules, and in the same way, attack unsaturated fatty acids resulting in a decrease in the membrane fluidity and the destruction of its function and structure [5,9,28,31,33,38]. Lipid oxidation decreases as a consequence of the decrease in ROS levels and improves the anti-oxidant defense system by phenolic compounds present in the extract; these findings are consistent with earlier studies [14,28,30]. GSH, as one of the most common bio-anti-oxidants, involves in the removal of free radicals, preserving the thiol groups of membrane proteins, as well as the substrate of glutathione peroxidase and glutathione-stransferase enzymes. Methotrexate directly inhibits the main enzymes involving in biosynthesis of glutathione as a result of which cellular oxidative stress increases $[5,9,28,31,33]$. Considering the anti-oxidant properties of chamomile extract, the amount of ROS in the cell decreases, which consequently causes the activity of the reductase glutathione enzyme to increase and contributes to the increase of GSH; these results are 
consistent with earlier studies [14,34]. The histopathological results of liver sections of rats in control group indicated normal hepatocytes with healthy cytoplasm and recognizable nucleus and sinusoids radially from the central vein to hepatocytes (Figures 3 A, B). In the MTX group rats, degeneration of liver cells and irregularities in the structure of liver lobules, dilatation and hyperemia of the central and portal veins were observed. Moreover, blood vessel sinusoids and their obstruction increased the number of activated Kupffer cells and infiltration of inflammatory cells in periportal area and the central vein (Figures $3 \mathrm{C}, \mathrm{D}$ ). This histopathological evidence is consistent with previous findings addressing methotrexate-induced hepatic damage [39-41]. Histopathologic results indicate that treatment with chamomile extract leads to a better effect in the healing of hepatic cells. In the $\mathrm{CE}_{200}$ group receiving $200 \mathrm{mg} / \mathrm{kg} /$ day of chamomile extract for 15 days, the level of hyperemia and inflammation were observed comparing to the other receiver group $\mathrm{CE}_{300}$ and the rate of healing was lower (Figures $3 \mathrm{E}, \mathrm{F}$ ). There were no pathologic lesions observed in the $\mathrm{CE}_{300}$ group receiving $300 \mathrm{mg} / \mathrm{kg} /$ day of the extract and all of them had a closely normal structure (Figures $3 \mathrm{G}, \mathrm{H}$ ). The results of previous studies on the protective effect of chamomile also demonstrate that due to its anti-oxidant properties chamomile is able to repair tissue damage induced by oxidative stress $[14,33]$.

\section{CONCLUSIONS}

The results of the present study indicate that methotrexate leads to liver dysfunction, decrease in protein synthesis, and oxidative damage. That are consequences of increasing lipid peroxidation, inflammation in the hepatic tissue and a decrease in the level of anti-oxidant defense system. The results indicate that chamomile hydroalcoholic extract decreases the oxidative stress, treats liver histopathological changes, and improves the anti-oxidant defense system. These show that chamomile extract can inhibit free radicals, which is the result of anti-oxidant property of phenolic compounds in the extract. Regarding the effects of the selective doses, the $300 \mathrm{mg} / \mathrm{kg} /$ day for 15 days was selected as the best protective dose against methotrexate-induced liver toxicity due to the most significant difference it has with the MTX group.

Funding: This research was funded by Islamic Azad University of Tehran, Science and Research Branch.

Acknowledgments: The authors sincerely appreciate Dr. Shahriari (Shahid Chamran University of Ahvaz, Iran) for his suggestions on the biochemical experiments and providing instrument facilities. Authors are also sincerely grateful to Dr. Parishani (the herbarium unit of Shahid Chamran University of Ahvaz) for plant identification.

Conflicts of Interest: The authors declare no conflict of interest. The funders had no role in the design of the study; in the collection, analyses, or interpretation of data; in the writing of the manuscript, or in the decision to publish the results.

\section{REFERENCES}

1. Sheikh MA, Tembhre M. Liver Toxicity and its Amelioration by Natural Antioxidants-A Review. Asian J Exp Sci. 2018 Jan;32(1):35-43

2. Jahovic N, Çevik H, Şehirli AÖ, Yeğen BÇ, Şener G. Melatonin prevents methotrexate-induced hepatorenal oxidative injury in rats. J Pineal Res. 2003 May;34(4):282-7.

3. Yaman T, Uyar A, Kaya MS, Keles ÖF, Uslu BA, Yener Z. Protective effects of silymarin on methotrexate-induced damages in rat testes. Braz J Pharm Sci. 2018 Jun;54(1).

4. Arpag H, Gül M, Aydemir Y, Atilla N, Yiğitcan B, Cakir T, et al. Protective Effects of Alpha-Lipoic Acid on Methotrexate-Induced Oxidative Lung Injury in Rats. J Invest Surg. 2018 Apr;31(2):107-13.

5. Vardi N, Parlakpinar H, Cetin A, Erdogan A, Cetin Ozturk I. Protective effect of $\beta$-carotene on methotrexateinduced oxidative liver damage. Toxicol pathol. 2010 Jun;38(4):592-7.

6. Swayeh NH, Abu-Raghif AR, Qasim BJ, Sahib HB. The protective effects of Thymus Vulgaris aqueous extract against Methotrexate-induced hepatic toxicity in rabbits. Int J Pharm Sci Rev Res. 2014 Dec;29:187-93.

7. Cure E, Kirbas A, Tumkaya L, Cure MC, Kalkan Y, Yilmaz A, et al. Protective effect of infliximab on methotrexateinduced liver injury in rats: Unexpected drug interaction. J Cancer Res Ther. 2015 Jan-Mar;11(1):164.

8. Sramek M, Neradil J, Veselska R. Much more than you expected: the non-DHFR-mediated effects of methotrexate. Biochim Biophys Acta Gen Subj. 2017 Mar;1861(3):499-503.

9. Babiak RMV, Campello AP, Carnieri EG, Oliveira MBM. Methotrexate: pentose cycle and oxidative stress. Cell Biochem Funct. 1998 Dec;16(4):283-93.

10. Caetano NN, Campello AP, Carnieri EG, Kluppel MLW, Oliveira MBM. Effect of methotrexate (MTX) on NAD (P)+ dehydrogenases of HeLa cells: malic enzyme, 2-oxoglutarate and isocitrate dehydrogenases. Cell Biochem Funct. 1997 Dec;15(4):259-64. 
11. Bupesh G, Amutha C, Vasanth S, Manoharan N, Raja RS, Krishnamoorthy R, et al. Hepatoprotective efficacy of Hypnea muciformis ethanolic extract on CCl4 induced toxicity in rats. Braz Arch Biol Technol. 2012 Dec;55(6):85763.

12. Srivastava JK, Shankar E, Gupta S. Chamomile: a herbal medicine of the past with a bright future. Mol Med Rep. 2010 Nov;3(6):895-901.

13. Amraei M, Bagrezaei F, Taghinejad H, Mohamadpour S. Hydroalcoholic Extract of Matricaria chamomilla effectively reduces inflammation induced by xylene in rat. J Bas Res Med Sci. 2015 Aug;2(2):30-6.

14. Rekka EA, Kourounakis AP, Kourounakis PN. Investigation of the effect of chamazulene on lipid peroxidation and free radical processes. Res Commun Mol Pathol Pharmacol. 1996 Jun;92(3):361-4.

15. Panche A, Diwan A, Chandra S. Flavonoids: an overview. J nutrit sci. 2016 Dec;5 :e47. doi: 10.1017/jns.2016.41.

16. Costa SL, Silva VDA, dos Santos Souza C, Santos CC, Paris I, Munoz P, et al. Impact of plant-derived flavonoids on neurodegenerative diseases. Neurotox Res. 2016 Jul;30(1):41-52.

17. Rezai-Zadeh K, Ehrhart J, Bai Y, Sanberg PR, Bickford P, Tan J, et al. Apigenin and luteolin modulate microglial activation via inhibition of STAT1-induced CD40 expression. J Neuroinflammation. 2008 Sep;5(1):41.

18. Bradford MM. A rapid and sensitive method for the quantitation of microgram quantities of protein utilizing the principle of protein-dye binding. Anal Biochem. 1976 May;72(1-2):248-54.

19. Buege JA, Aust SD. Microsomal lipid peroxidation. Methods Enzymol. 1978;52:302-10.

20. Benzie IF, Strain JJ. Ferric reducing/antioxidant power assay: Direct measure of total antioxidant activity of biological fluids and modified version for simultaneous measurement of total antioxidant power and ascorbic acid concentration. Methods Enzymol. 1999;299:15-27.

21. Ellman GL. Tissue sulfhydryl groups. Arch Biochem Biophys. 1959 May;82(1):70-7.

22. Paglia DE, Valentine WN. Studies on the quantitative and qualitative characterization of erythrocyte glutathione peroxidase. J Lab Clin Med. 1967 Jul;70(1):158-69.

23. Kono Y. Generation of superoxide radical during autoxidation of hydroxylamine and an assay for superoxide dismutase. Arch Biochem Biophys. 1978 Feb;186(1):189-95.

24. Koroliuk MA, Ivanova LI, Maĭorova IG, Tokarev VE. A method of determining catalase activity. Lab Delo. 1988;(1):16-9.

25. Mehrzadi S, Fatemi I, Esmaeilizadeh M, Ghaznavi H, Kalantar H, Goudarzi M. Hepatoprotective effect of berberine against methotrexate induced liver toxicity in rats. Biomed Pharmacother. 2018 Jan;97:233-9.

26. Shibayama Y, Ushinohama K, Ikeda R, Yoshikawa Y, Motoya T, Takeda Y, et al. Effect of methotrexate treatment on expression levels of multidrug resistance protein 2, breast cancer resistance protein and organic anion transporters Oat1, Oat2 and Oat3 in rats. Cancer Sci. 2006 Nov;97(11):1260-6.

27. Shibayama Y, Takeda Y, Yamada K. Effect of methotrexate treatment on expression levels of organic anion transporter polypeptide 2, P-glycoprotein and bile salt export pump in rats. Biol Pharm Bull. 2009 Mar;32(3):4936.

28. Akbulut S, Elbe H, Eris C, Dogan Z, Toprak G, Otan E, et al. Cytoprotective effects of amifostine, ascorbic acid and $\mathrm{N}$-acetylcysteine against methotrexate-induced hepatotoxicity in rats. World J Gastroenterol. 2014 Aug;20(29):10158-65.

29. Tavakol HS, Farzad K, Fariba M, Abdolkarim C, Hassan G, Seyed-Mostafa HZ, et al. Hepatoprotective effect of Matricaria chamomilla. $L$ in paraquat induced rat liver injury. Drug Res (Stuttg). 2015 Feb;65(2):61-4.

30. Sebai H, Jabri MA, Souli A, Hosni K, Rtibi K, Tebourbi O, et al. Chemical composition, antioxidant properties and hepatoprotective effects of chamomile (Matricaria recutita L.) decoction extract against alcohol-induced oxidative stress in rat. Gen Physiol Biophys. 2015 Jul;34(3):263-75.

31. Tunalı-Akbay T, Sehirli O, Ercan F, Sener G. Resveratrol protects against methotrexate-induced hepatic injury in rats. J Pharm Pharm Sci. 2010;13(2):303-10.

32. Mhatre BA, Marar T. Protective effect of Morinda citrifolia L.(fruit extract) on methotrexate-induced toxicitieshematological and biochemical studies. Cogent Biol. $2016 \mathrm{Jul} ; 2(1): 1207879$.

33. Armagan I, Bayram D, Candan IA, Yigit A, Celik E, Armagan HH, et al. Effects of pentoxifylline and alpha lipoic acid on methotrexate-induced damage in liver and kidney of rats. Environ Toxicol Pharmacol. 2015 May;39(3):1122-31.

34. Jabri MA, Sani M, Rtibi K, Marzouki L, El-Benna J, Sakly M, et al. Chamomile decoction extract inhibits human neutrophils ROS production and attenuates alcohol-induced haematological parameters changes and erythrocytes oxidative stress in rat. Lipids Health Dis. 2016 Mar;15(1):65.

35. Munir N, lqbal AS, Altaf I, Bashir R, Sharif N, Saleem F, et al. Evaluation of antioxidant and antimicrobial potential of two endangered plant species Atropa belladonna and Matricaria chamomilla. Afr J Tradit Complement Altern Med. 2014 Aug;11(5):111-7.

36. Çetin A, Kaynar L, Kocyigit I, Hacioglu SK, Saraymen R, Ozturk A, et al. Role of grape seed extract on methotrexate induced oxidative stress in rat liver. Am J Chin Med. 2008;36(5):861-72.

37. Hemeida RA, Mohafez OM. Curcumin attenuates methotraxate-induced hepatic oxidative damage in rats. J Egypt Natl Canc Inst. 2008 Jun;20(2):141-8.

38. Kose E, Sapmaz HI, Sarihan E, Vardi N, Turkoz Y, Ekinci N. Beneficial effects of montelukast against methotrexateinduced liver toxicity: a biochemical and histological study. ScientificWorldJournal. 2012;2012:987508. doi:10.1100/2012/987508. 
39. Friedman SL. Molecular regulation of hepatic fibrosis, an integrated cellular response to tissue injury. J Biol Chem. 2000 Jan;275(4):2247-50.

40. Çakır T, Baştürk A, Polat C, Aslaner A, Durgut H, Şehirli AÖ, et al. Does alfa lipoic acid prevent liver from methotrexate induced oxidative injury in rats? Acta Cir Bras. 2015 Apr;30(4):247-52.

41. Yucel Y, Oguz E, Kocarslan S, Tatli F, Gozeneli O, Seker A, et al. The effects of lycopene on methotrexate-induced liver injury in rats. Bratisl Lek Listy. 2017;118(4):212-6.

(C) (5) 2020 by the authors. Submitted for possible open access publication under the terms and
conditions of the Creative Commons Attribution (CC BY NC) license
(https://creativecommons.org/licenses/by-nc/4.0/). 